\title{
MICROCOLONY SIZE OF MICROBES ON HUMAN SKIN
}

\author{
Dorothy A. Somerville* AND W. C. Noble \\ Department of Bacteriology, St John's Hospital for Diseases of the Skin, \\ Homerton Grove, London E9 6BX
}

It has long been clear that large numbers of bacteria reside on the skin surface. Price (1938) found populations of four million bacteria on the hands; Evans et al. (1950) recorded populations of 277,000 anaerobes and 1430 aerobes per $\mathrm{cm}^{2}$ when the shoulders were sampled by scraping. Yet there is an apparent divergence in results because Williamson (1965) reported mean values of $2.41 \times 10^{6}$ per $\mathrm{cm}^{2}$ in the axilla and $2 \times 10^{5}$ per $\mathrm{cm}^{2}$ on the forehead obtained by scrubbing techniques, whilst Ulrich (1965) at the same symposium reported values of 106 and 348 respectively obtained by contact plates. It is clear that scrubbing techniques disperse the bacteria and tend to measure the number of single cells, whilst contact techniques measure the number of viable aggregates or colonies.

Holt (1971) exploited this apparent discrepancy to estimate the number of cells in each aggregate. He used velvet-pad replicas as a measure of the number of aggregates and a scrubbing technique as a measure of the total bacterial cells, and was able to visualise the skin flora as a series of comparatively large microcolonies. Holt's peak value for a microcolony, 70,000 cells per aggregate, seemed extraordinarily large; we decided to try to confirm Holt's concept and to extend it to anaerobic bacteria. This paper reports the findings.

\section{MATERIAL AND METHODS}

Ten healthy persons, five male and five female, were sampled on the forehead, anterior forearm, and periumbilicus. The forehead was chosen as a site likely to carry large numbers of Corynebacterium acnes, the forearm as a normal skin site liable to environmental contamination, and the periumbilicus as a site unlikely to be exposed to contamination. Contact plates were poured in plastic petri dishes with serum agar (Oxoid Blood Agar Base +5 per cent. horse serum) or thioglycollate tween agar (Difco Thioglycollate Medium without indicator to which was added 1 per cent. Tween 80).

The scrubbers were teflon rods in teflon cups and the sampling fluid was phosphate

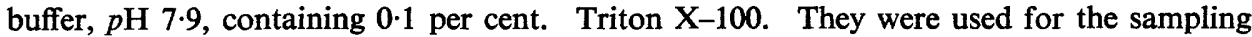
method described by Williamson, which has been shown to remove 85 per cent. of removable bacteria in the 1st min. After sampling, the fluid was serially diluted in ten-fold steps in buffer with 0.05 per cent. Triton X-100; $0.05-\mathrm{ml}$ drops were inoculated on blood agar (Oxoid Blood Agar Base +5 per cent. horse blood) and thioglycollate tween agar. Serum and blood plates were incubated for 2 days at $37^{\circ} \mathrm{C}$. Thioglycollate tween plates were incubated for 5 days at $37^{\circ} \mathrm{C}$ in a MacIntosh and Fildes jar in an atmosphere of hydrogen in the conventional manner.

Received 27 Sept. 1972; accepted 27 Dec. 1972.

* Present address: Department of Bacteriology, Royal Infirmary, Glasgow.

Requests for reprints should be sent to W. C. N.

J. MED. MICROBIOL.-VOL. 6 (1973) 


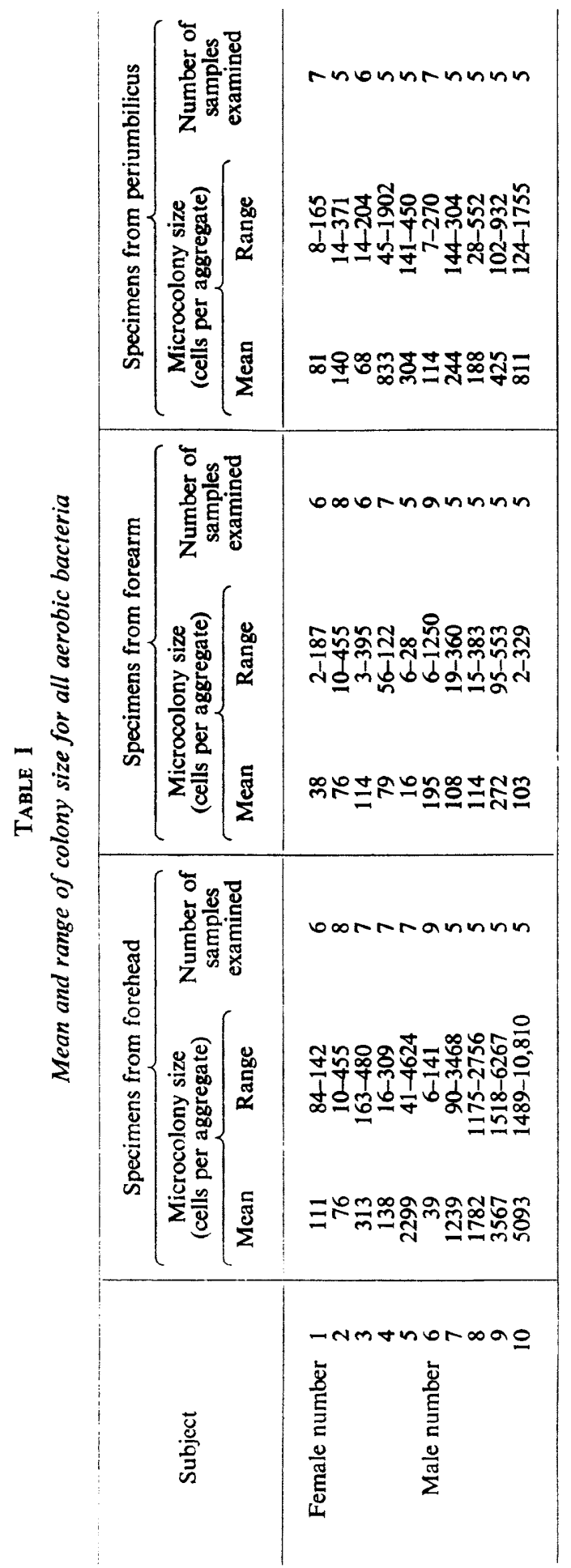




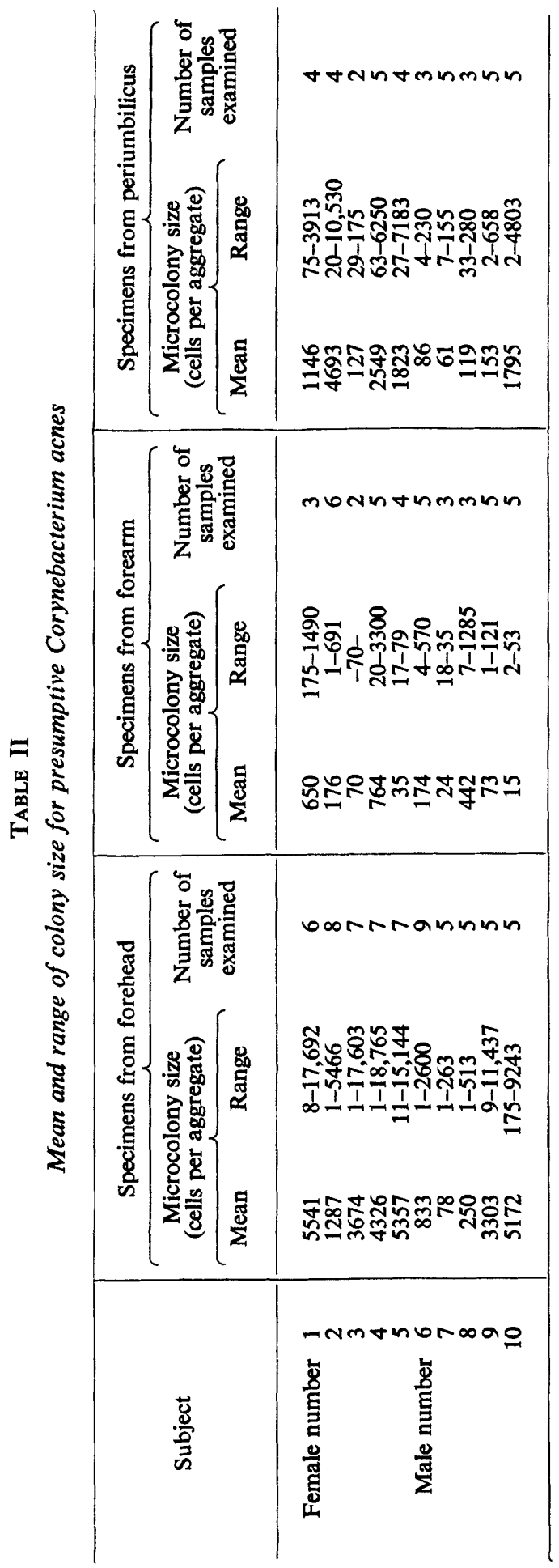


Some attempt was made to distinguish between cocci and diphtheroids on the aerobic plates, but the results reported here are for total aerobic bacteria. All strains growing anaerobically were recorded. In this paper, obligate anaerobic corynebacteria with domed colonies are referred to as $C$. acnes. In some instances all anaerobes appeared to be $C$. acnes but in other instances this was not so.

Mean microcolony size was obtained by dividing the scrub counts per $\mathrm{cm}^{2}$ by the contact counts per $\mathrm{cm}^{2}$.

\section{RESULTS}

The results for two groups of micro-organisms are shown in tables I and II; the mean microcolony size, the range of microcolony sizes, and number of samples are shown. Individual counts for one subject are shown in table III. There is clearly great variation between individuals and within the consecutive results for each individual. Differences between individuals were statistically significant for the aerobic count on the forehead and periumbilicus $(\mathrm{P}=<0.001)$ but, perhaps surprisingly, were not significant for $C$. acnes.

TABLE III

Sample results for one individual; aerobic and C. acnes counts on the forehead

\begin{tabular}{|c|c|c|c|c|c|c|}
\hline \multirow{3}{*}{ Date } & \multicolumn{3}{|c|}{ Results for all aerobes } & \multicolumn{3}{|c|}{ Results for presumptive $C$. acnes } \\
\hline & \multicolumn{2}{|c|}{ Colony count per $\mathrm{cm}^{2}$} & \multirow{2}{*}{$\begin{array}{l}\text { Colony size } \\
\text { (cells per } \\
\text { aggregate) }\end{array}$} & \multicolumn{2}{|c|}{ Colony count per $\mathrm{cm}^{2}$} & \multirow{2}{*}{$\begin{array}{l}\text { Colony size } \\
\text { (cells per } \\
\text { aggregate) }\end{array}$} \\
\hline & $\begin{array}{l}\text { by contact } \\
\text { plate }\end{array}$ & $\begin{array}{c}\text { by scrub } \\
\text { method }\end{array}$ & & $\begin{array}{c}\text { by contact } \\
\text { plate }\end{array}$ & $\begin{array}{l}\text { by scrub } \\
\text { method }\end{array}$ & \\
\hline $\begin{array}{l}24 \text { April } \\
26 \text { April } \\
27 \text { April } \\
28 \text { April } \\
1 \text { May }\end{array}$ & $\begin{array}{r}53 \\
14 \\
34 \\
115 \\
72\end{array}$ & $\begin{array}{l}17 \times 10^{4} \\
15 \times 10^{4} \\
21 \times 10^{4} \\
17 \times 10^{4} \\
27 \times 10^{4}\end{array}$ & $\begin{array}{r}3228 \\
10,810 \\
6193 \\
1489 \\
3747\end{array}$ & $\begin{array}{r}105 \\
113 \\
74 \\
126 \\
84\end{array}$ & $\begin{array}{l}91 \times 10^{4} \\
20 \times 10^{3} \\
32 \times 10^{4} \\
12 \times 10^{5} \\
30 \times 10^{4}\end{array}$ & $\begin{array}{r}8648 \\
175 \\
4268 \\
9243 \\
3525\end{array}$ \\
\hline
\end{tabular}

There is great variation in the $C$. acnes counts within consecutive individual samples and this may reflect the state of disturbance of the skin flora. $C$. acnes is most unlikely to multiply near the skin surface and the presence of $C$. acnes cells at the surface presumably depends on expression from a follicle or sebaceous-gland orifice.

\section{Microcolony size in relation to sex}

In these investigations, males had significantly larger microcolonies of aerobes on the forehead than did females $(P=<0.001)$. The mean aerobic forehead-microcolony sizes were 2056 bacterial cells for males and 590 for females. The reverse was true for $C$. acnes of which on the forehead and periumbilicus the female had the larger microcolonies-forehead: male 1924, female 4725; periumbilicus: male 506, female $2297(\mathrm{P}=<0.05)$. All other differences between the sexes were not significant. 


\section{Visualisation of microcolonies}

Microcolonies can be seen on skin sampled by the surface-biopsy technique (Marks and Dawber, 1971). Adhesive on a glass slide is used to remove the desquamating epithelium which can then be Gram-stained. Threedimensional colonies can be seen under the oil immersion lens though it has so far proved impossible to estimate visually the number of organisms in these microcolonies.

\section{Discussion}

Holt's (1971) figure of 70,000 cells in a microcolony had seemed extraordinarily large, for such a colony ought to be visible to the unaided eye. The largest mean aerobic microcolony size encountered in this series was 10,810 cells; the largest $C$. acnes colony 18,765 cells but it must be emphasised that this was the mean value for one $\mathrm{cm}^{2}$ of skin surface.

There were significant differences between the individuals in this survey and it may be that Holt's figure represents a person at the extreme of the range. It is also possible that the use of velvet pads rather than direct contact plates underestimated the number of aggregates, thus leading to an exaggerated colony size.

The concept of large colonies at or near the skin surface presumably explains the difficulties experienced in degerming the skin. Wilson (1970) reported that, when antibacterial soaps were used, the number of bacteria on skin, measured by washing or dispersal techniques, fell significantly; but, in the same individuals, a significant drop could not be shown by contact techniques. Presumably the action of an antibacterial soap is to reduce the number of microbes in a microcolony without significantly reducing the number of microcolonies. Even an efficient agent with a "kill" of greater than 99.9 per cent. would fail to eradicate many of the microcolonies observed in this series.

\section{SUMMARY}

The microcolony sizes of the aerobic and anaerobic cutaneous bacterial flora have been examined by a comparison of the number of viable aggregates and the total viable cells per $\mathrm{cm}^{2}$ of skin. The mean microcolony size was often of the order of $10^{4}$ cells and counts in excess of $10^{5}$ cells have been recorded. The importance of these microcolonies in relation to skin disinfection is discussed.

\section{REFERENCES}

Evans, C. A., Smith, W. M., Johnston, Elizabeth A., and Giblett, Eloise R. 1950. Bacterial flora of the normal human skin. J. Invest. Derm., 15, 305.

Holt, R. J. 1971. Aerobic bacterial counts of human skin after bathing. J. Med. Microbiol., 4, 319.

MARKs, R., AND DAWBER, R. P. R. 1971. Skin surface biopsy: an improved technique for the examination of the horny layer. Br.J. Derm., 84, 117.

PRICE, P. B. 1938. The bacteriology of normal skin; a new quantitative test applied to a study of the bacterial flora and the disinfectant action of mechanical cleansing. $J$. Infect. Dis., 63, 301. 
UlRICH, J. A. 1965. Dynamics of bacterial skin populations. In Skin bacteria and their role in infection, edited by H. I. Maibach and G. Hildick-Smith, New York, p. 219.

Williamson, P. 1965. Quantitative estimation of cutaneous bacteria. In Skin bacteria and their role in infection, edited by H. I. Maibach and G. Hildick-Smith, New York, p. 3.

Wilson, Patricia E. 1970. A comparison of methods for assessing the value of antibacterial soaps. J. Appl. Bact., 33, 574. 